\title{
Assessment of the antimicrobial activity of lactic acid bacteria isolated from two fermented maize products - ogi and kunnu-zaki
}

\author{
Omemu, Adebukunola Mobolaji and Faniran, Omowunmi Wuraola \\ Department of Microbiology, University of Agriculture, Abeokuta (UNAAB), PMB, 2240, Nigeria. \\ E-mail: bjomemu@yahoo.com; amomemu@gmail.com; omemuam@unaab.edu.ng
}

Received 8 June 2010; received in revised form 13 January 2011; accepted 17 January 2011

\begin{abstract}
The lactic acid bacteria (LAB) used in this study were isolated from two traditional fermented maize products- ogi and kunnu-zaki. The antimicrobial activities of the isolated LAB against some indicator organisms (Staphylococcus aureus, Escherichia coli, Klebsiella pneumonia, Proteus mirabilis and Bacillus cereus) was investigated. The LAB population in the ogi samples ranged from $5.39 \mathrm{log} \mathrm{cfu} / \mathrm{g}$ to $6.40 \mathrm{log} \mathrm{cfu} / \mathrm{g}$ while that of kunnu-zaki ranged from $6.11 \mathrm{log} \mathrm{cfu} / \mathrm{g}$ to 6.70 $\log \mathrm{cfu} / \mathrm{g}$. The lactic acid bacteria isolated were identified as Lactobacillus plantarum, L. fermentum, L. lactis, L. acidophilus, L. mesenteroides, $L$. casei, and Streptococcus thermophilus. Cell free supernatant of the LAB was able to inhibit the growth of the indicator organism used. The largest zone of inhibition was $11 \mathrm{~mm}$ produced by $L$. plantarum against Klebsiella pnuemoniae while the least zone of inhibition was $3 \mathrm{~mm}$ produced by L. acidophilus against $E$. coli. The $\mathrm{LAB}$ tested also produced various antimicrobial compounds such as lactic acid, diacetyl and hydrogen peroxide and quantitative estimation of these antimicrobial compounds was carried out. The highest yield of lactic acid was $2.18 \mathrm{~g} / \mathrm{L}$ produced by $S$. thermophilus, highest yield of diacetyl was $2.5 \mathrm{~g} / \mathrm{L}$ produced by $L$. plantarum while the highest yield of hydrogen peroxide was $0.006 \mathrm{~g} / \mathrm{L}$ produced by L. plantarum.
\end{abstract}

Keywords: antimicrobial, diacetyl, hydrogen peroxide, lactic acid bacteria and lactic acid

\section{INTRODUCTION}

Lactic acid bacteria (LAB) are widely distributed in nature, they are typically involved in a large number of the spontaneous food fermentation, and they have been extensively studied for their involvement in the production of many indigenous fermented foods (Holzapfel et al., 1995). Some members of LAB produce bacteriocins and bacteriocins-like substances which may inhibit growth of spoilage and pathogenic microorganisms (Klaenhammer, 1988). Lactic acid fermentation of cereal-based foods is a traditional technology in Africa and has long been used in the processing of different foods (Mensah, 1997; Oyewole 1997). Maize and sorghum are often used for preparation of most of these foods. Some serve as weaning or staple foods, while some are fermented alcoholic beverages (Umoh and Fields, 1981; Akobundu and Hoskins, 1982).

In Nigeria, ogi and Kunnu-zaki are two of the most common lactic acid fermented products popular with consumers. Consumption of these fermented foods has many advantages including enhanced nutritional value, digestibility, therapeutic benefits, and safety against pathogens (Oranusi et al., 2003).

The traditional methods of preparation of ogi and Kunnu-zaki have been described and there is general agreement on the dominance and beneficial effects of lactic acid bacteria (LAB) in the fermentation processes of these foods (Odunfa, 1985; Teniola and Odunfa, 1995; Omemu et al., 2007).
The LAB contribute to the enhancement of the organoleptic attributes of these foods, as well as to their preservation and microbial safety (Hounhouigan et al., 1993; Olsen, et al., 1995; Caplice and Fitzgerald, 1999; Calderon et al., 2001).

The primary antimicrobial effect exerted by $L A B$ is the production of lactic acid and reduction of $\mathrm{pH}$ (Daeschel, 1989). In addition, LAB produce various antimicrobial compounds, which can be classified as low-molecularmass (LMM) compounds such as hydrogen peroxide $\left(\mathrm{H}_{2} \mathrm{O}_{2}\right)$, carbon dioxide $\left(\mathrm{CO}_{2}\right)$, diacetyl (2,3-butanedione), uncharacterized compounds, and high-molecular-mass (HMM) compounds like bacteriocins (Jay, 1982; Piard and Desmazeaud, 1992). All of which can antagonize the growth of some spoilage and pathogenic bacteria in foods. The antimicrobial-producing LAB may be used as protective cultures to improve the microbial safety of foods and they also play an important role in the preservation of fermented foods, which is usually achieved by inhibition of contaminating spoilage bacteria such as Pseudomonas and pathogens such as Staphylococcus aureus, Salmonella spp. and Listeria monocytogenes (Buckenhuskes, 1993; Brinkten et al., 1994; Olasupo et al., 1995).

The aim of the present study is to assess antimicrobial activity of some lactic acid bacteria strains isolated from traditional fermented maize products against some pathogens of clinical significance. Preliminary quantitative estimation of the different antimicrobial 
substances produced by each of the LAB species isolated from ogi and kunnu-zaki were also determined.

\section{MATERIALS AND METHODS}

\section{Collection of samples and bacterial strains}

Traditionally prepared samples of fermented ogi and kunnu-zaki were randomly obtained from five different markets in Abeokuta, South-west Nigeria. Samples were transported immediately to the laboratory for microbiological analysis.

The indicator isolates used were obtained from Department of Medical Microbiology and Parasitology, University College Hospital, Ibadan, Nigeria.

\section{Isolation of lactic acid bacteria}

Each sample $(25 \mathrm{~mL})$ was mixed with $225 \mathrm{~mL}$ of buffered peptone water (BPW, Oxoid) to obtain a 1: 10 dilution. Serial dilutions of the samples were prepared in $0.1 \%$ peptone water. MRS agar was supplemented with $0.01 \%$ sodium azide to inhibit the growth of Gram-negative bacteria. The diluted sample was streaked on the MRS agar plates and then incubated anaerobically at $30^{\circ} \mathrm{C}$ for $48 \mathrm{~h}$. Colonies were isolated, sub-cultured and purified by repeated streaking.

The morphological, physiological and biochemical examination of the isolates were determined by the standard procedure of Gram staining, catalase test and gas production test. Colonies of catalase negative, Grampositive rods or cocci were presumed to be LAB. API 50 $\mathrm{CHL}$ stripes were used to identify all isolates to species level. Working cultures were prepared as slants on MRS agar for $L A B$ or nutrient agar supplement for the indicators, and stored at $4^{\circ} \mathrm{C}$.

\section{Determination of the antimicrobial activities of the LAB isolates}

Cell-free culture supernatants for antibacterial assay was prepared by growing the LAB isolates in MRS broth at 37 ${ }^{\circ} \mathrm{C}$ and centrifuged at $12,000 \times \mathrm{g}$ for $10 \mathrm{~min}$. The antimicrobial activity of the cell-free culture supernatants of isolated $\mathrm{LAB}$ against the indicator organisms was determined by the agar well diffusion assay according to the method by Elaine et al., (1994). Aliquots of supernatants $(100 \mu \mathrm{L})$ were placed in wells $(6 \mathrm{~mm}$ diameter) cut in cooled soft nutrient agar plates previously seeded $(1 \% \mathrm{v} / \mathrm{v})$ with the appropriate indicator strains. The plates were incubated under optimal conditions for growth of the target microorganisms after which they were examined for clear zones around the wells. The diameters of the growth inhibition zones were measured and recorded in millimetre $(\mathrm{mm})$. The indicator strains used in this study are Staphylococcus aureus, Escherichia coli, Klebsiella pneumonia, Proteus mirabilis and Bacillus cereus.

\section{Determination of Lactic acid, hydrogen peroxide and diacetyl production by the LAB isolates}

The test organisms were grown of MRS broth for $72 \mathrm{~h}$ and samples were taken at $12 \mathrm{~h}$ interval for Lactic acid, hydrogen peroxide and diacetyl production.

\section{Hydrogen peroxide}

Diluted sulphuric acid (25 mL) was added to $25 \mathrm{~mL}$ of the broth culture of the test organism. Titration was carried out with $0.1 \mathrm{~N}$ potassium permanganate each $\mathrm{mL}$ of $0.1 \mathrm{~N}$ potassium permanganate is equivalent to $1.070 \mathrm{mg}$ of hydrogen peroxide. A disclourization of the sample was regarded as end point (AOAC, 1990).

\section{Lactic acid}

$\mathrm{NaOH}(0.1 \mathrm{~N})$ was titrated against $25 \mathrm{~mL}$ broth culture of the organism using 3 drops of phenolphthalein as indicator. The $\mathrm{NaOH}$ was added until the colour changes to pink. Each millilitre of $\mathrm{NaOH}$ is equivalent to $90.08 \mathrm{mg}$ of lactic acid (AOAC, 1990).

\section{Diacetyl}

Twenty five $\mathrm{mL}$ of broth cultures were transfered into conical flasks and $7.5 \mathrm{~mL}$ of hydroxylamine solution were used for the residual titration. Titration was done with 0.1 $\mathrm{N} \mathrm{HCl}$ to a greenish end point using bromophenol blue as indicator. The equivalent factor of $\mathrm{HCl}$ to diacetyl is 21.5 mg (AOAC, 1990).

\section{Statistical analysis}

The data obtained were subjected to analysis of variance, mean differences determined by the least square difference (LSD) test and bivariate correlations determined using SPSS 10.0 for windows software.

\section{RESULTS}

Result presented in Table 1 shows the $\mathrm{pH}$ and LAB population in the ogi and kunnu zaki samples evaluated from the different markets. The $\mathrm{pH}$ of the ogi samples ranged from 2.87 to 3.67 while the $\mathrm{pH}$ of the kunnu-zaki samples ranged from 3.87 to 4.10 . The LAB population in the ogi samples ranged from $5.39 \mathrm{log} \mathrm{cfu} / \mathrm{g}$ to $6.40 \mathrm{log}$ $\mathrm{cfu} / \mathrm{g}$ while that of kunnu-zaki ranged from $6.11 \mathrm{log} \mathrm{cfu} / \mathrm{g}$ to $6.70 \mathrm{log} \mathrm{cfu} / \mathrm{g}$.

The $\mathrm{LAB}$ species isolated from ogi samples were Lactobacillus plantarum, $L$. lactis, $L$. casei, $L$. mesenteroides and $L$. acidophilus while Lactobacillus plantarum, $L$. fermentum, $L$. fermentum, $L$. lactis, $L$. mesenteroides and Streptococcus thermophillus were obtained from kunnu-zaki samples (Table 2).

The indicator spoilage/ pathogens used in this study were Staphylococcus aureus, E. coli, K. pneumonia, P. mirabilis and $B$. cereus. 
he LAB species isolated from the fermented maize products were able to inhibit the tested indicator organisms with varied zone of inhibition. With the exception of $E$. coli, L. plantarum produced significantly $(p<0.05)$ higher zone of inhibition against all the pathogens tested as compared to the other LAB tested. The largest zone of inhibition of $11 \mathrm{~mm}$ was produced by $L$. plantarum against $K$. pneumonia and this was significantly $(p<0.05)$ higher than the least zone of inhibition of $3 \mathrm{~mm}$ produced by $L$. acidophilus against $E$. coli. Lactobacillus acidophilus and L. fermentum were not able to inhibit Proteus sp. since no zone of inhibition was observed.

Table 1: Mean $\mathrm{pH}$ and LAB population in ogi and kunnuzaki samples.

\begin{tabular}{lllll}
\hline Product & $\begin{array}{l}\text { Market } \\
\text { code }\end{array}$ & $\begin{array}{l}\text { No. of } \\
\text { samples }\end{array}$ & $\begin{array}{l}\text { Mean } \\
\mathrm{pH}\end{array}$ & $\begin{array}{l}\text { LAB } \\
\text { population } \\
\text { (log cfu/g) }\end{array}$ \\
\hline OGI & MK1 & 10 & 3.02 & 5.39 \\
& MK2 & 10 & 3.42 & 6.40 \\
& MK3 & 14 & 3.25 & 6.23 \\
& MK4 & 13 & 2.87 & 6.43 \\
KUNNU & MK5 & 9 & 3.67 & 6.36 \\
& MK1 & 11 & 4.07 & 6.15 \\
& MK2 & 9 & 4.05 & 6.70 \\
& MK3 & 8 & 3.91 & 6.53 \\
& MK4 & 10 & 4.10 & 6.12 \\
& MK5 & 9 & 3.87 & 6.11 \\
\hline
\end{tabular}

Table 2: Lactic acid bacteria isolated from fermented ogi and Kunnu-zaki.

\begin{tabular}{ll}
\hline Product & Associated lactic acid bacteria \\
\hline Ogi & Lactobacillus plantarum \\
& L. fermentum \\
& L. lactis \\
& L. mesenteroides \\
& L. casei \\
& L. acidophilus \\
& Lactobacillus plantarum \\
Kunnu-zaki & L. fermentum \\
& L. lactis \\
& L. mesenteroide \\
& Streptococcus thermophillus \\
\hline
\end{tabular}

Preliminary quantitative estimation of different antimicrobial substances produced by each of the LAB species isolated from ogi and kunnu-zaki was determined. The highest yield of lactic acid $(2.18 \mathrm{~g} / \mathrm{L})$ was produced by $S$. thermophillus at $36 \mathrm{~h}$ while the lowest yield of $0.73 \mathrm{~g} / \mathrm{L}$ was produced by $L$. plantarum at $12 \mathrm{~h}$. L. plantarum produced the highest amount of hydrogen peroxide $(0.006$ $\mathrm{g} / \mathrm{L}$ ) at $12 \mathrm{~h}$ while $L$. acidophilus produced the lowest amount $(0.0009 \mathrm{~g} / \mathrm{L})$ at $12 \mathrm{~h}$. For diacetyl, the highest $(2.5$ $\mathrm{g} / \mathrm{L}$ ) was produced by $L$. plantarum at $24 \mathrm{~h}$ while the least $(0.1 \mathrm{~g} / \mathrm{L})$ was produced by $\mathrm{L}$. lactis at $60 \mathrm{~h}$.

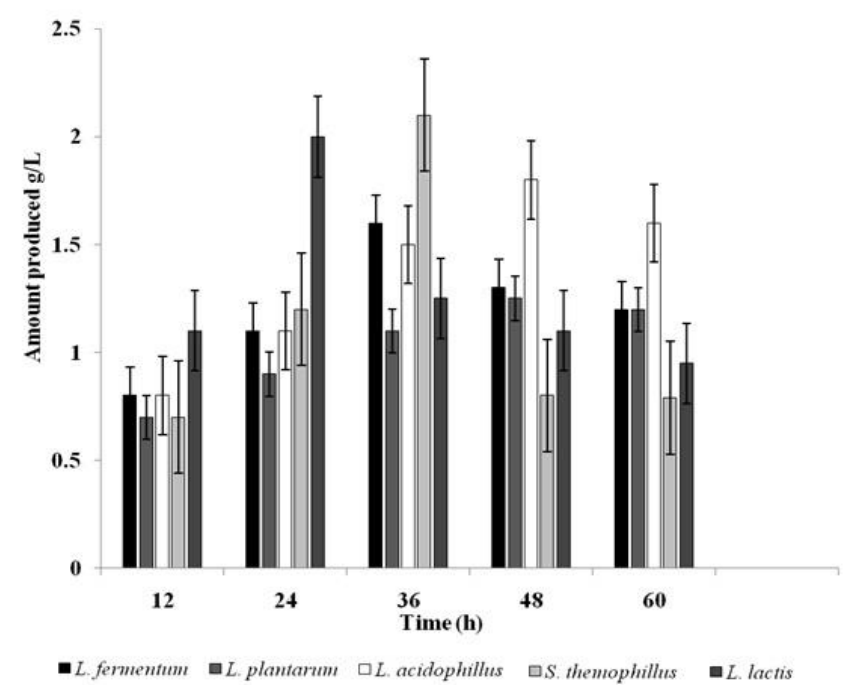

Figure 1: Amount of lactic acid produced by LAB isolates with time. Error bars represent standard errors of mean of triplicate determinations.

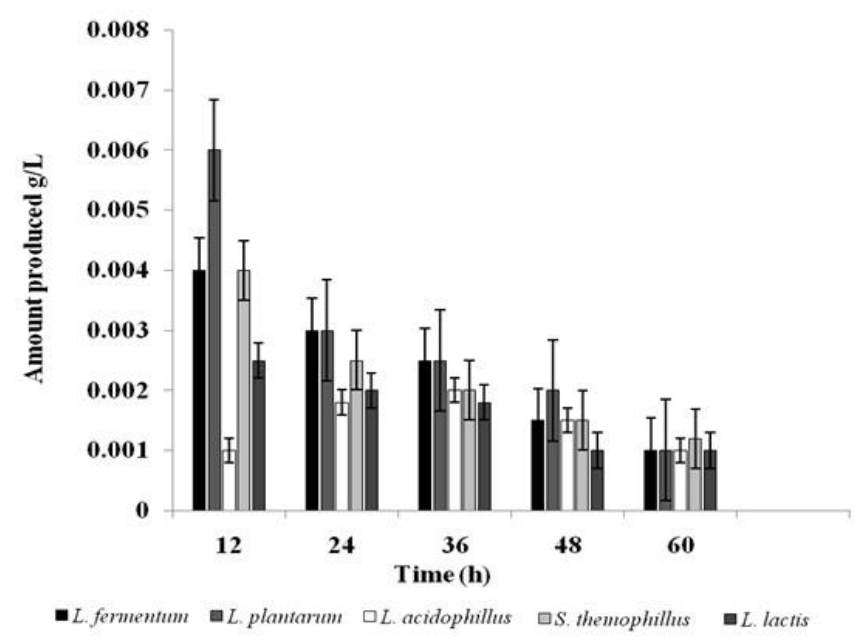

Figure 2: Amount of hydrogen peroxide produced by LAB isolates with time. Error bars represent standard errors of mean of triplicate determinations.

\section{DISCUSSION}

The identification carried out for representative Lactobacillus strains from the fermented food products demonstrated the dominance of $L$. acidophilus, $L$. casei $L$. fermentum L. lactis and L. plantarum. These identified Lactobacillus species were in accordance with those earlier identified from similar fermented food products (Halm et al., 1993; Wakil et al., 2004).

Microbial food safety is an increasing public health concern worldwide and many Gram negative bacteria such as E. coli, Klebsiella sp. together with Gram positive 
Table 3: Zone of inhibitions ( $\mathrm{mm}$ ) of pathogens by lactic acid bacteria isolated from ogi and kunnu-zaki

\begin{tabular}{llllll}
\hline LAB isolates & B. cereus & S. aureus & P. mirabilis & K. pneumoniae & E. coli \\
\hline L. plantarum & +8 & +8 & +6 & +11 & $\mathrm{NZ}$ \\
L. lactis & +7 & +7 & +4 & +7 & +7 \\
L. acidophilus & +7 & +5 & $\mathrm{NZ}$ & +6 & +3 \\
L. casei & +7 & +6 & +7 & +5 & +4 \\
L. fermentum & +7 & +5 & $\mathrm{NZ}$ & +6 & +5 \\
L. mesenteroides & +6 & +6 & +4 & +8 & +5 \\
Streptococcus thermophillus & +7 & +4 & +10 & +7 & +5 \\
\hline
\end{tabular}

NZ: no zone of inhibition, indicating resistance of the organism to the antibiotics

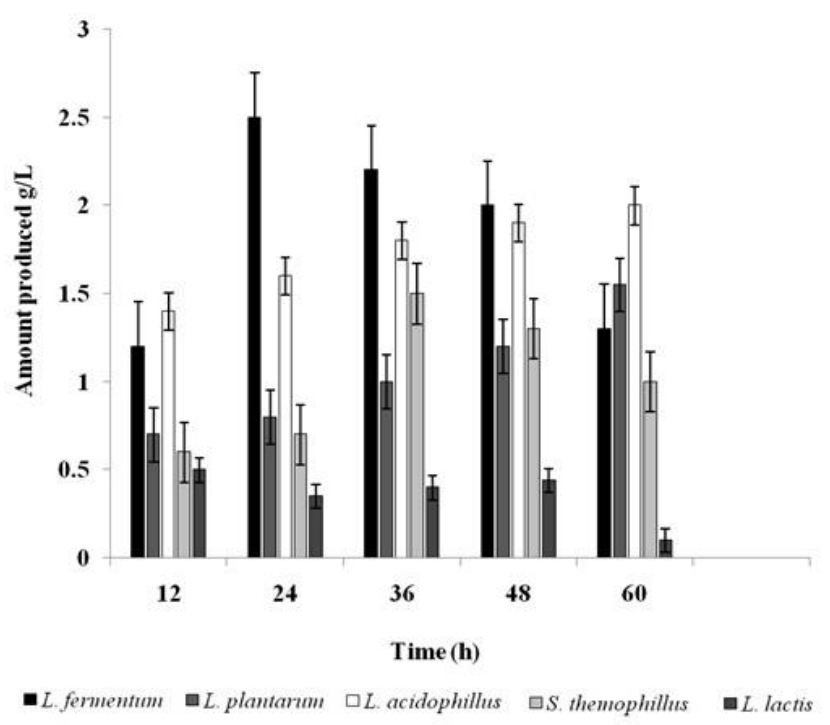

Figure 3: Amount of diacetyl produced by LAB isolates with time. Error bars represent standard errors of mean of triplicate determinations.

bacteria such as $S$. aureus have been implicated in food borne diseases (Mead et al., 1999). Ogunshe et al. (2005) also isolated some Gram negative bacteria of clinical importance from a fermented food condiment.

Several studies have shown that pathogens such as enterotoxigenic E. coli, Shigella flexneri, Salmonella typhimurium and $B$. cereus are adversely affected when present in traditional fermented foods (Kingamkono et al., 1995; Kunene et al., 2000; Obadina et al., 2006). Some of the antimicrobial properties exhibited by these fermenetd foods may be as a result of the low $\mathrm{pH}$ of the food as well as metabolites produced by microoragnisms such as $L A B$ involved in the fermentation. The pathogens used in this study were sensitive to the LAB metabolites. Brooks et al., 1998 reported rapid development of resistance by Staphylococcus sp. to antimicrobial agents. However, the Staphylococcus aureus used in this study was sensitive to the entire LAB used against it. Lactic acid bacteria are known to produce antimicrobial substances mainly in the form of organic acids and metabolites (Obadina et al., 2006). Antimicrobial activity caused by growth of lactic acid bacteria may be due to decrease in $\mathrm{pH}$, depletion of nutrients and production of antimicrobial compounds (Olsen et al., 1995), including bacteriocins (Parente and Ricciardi, 1999), and various organic acids such as lactic acids, acetic acid.

The LAB isolated from fermented ogi and kunnu-zaki in this study produced different antimicrobial compounds the quantity of which varies with time. The increase in the production of lactic acid with time has been attributed to lowered $\mathrm{pH}$ which permit the growth of $L A B$. The inhibitory effect of hydrogen peroxide from $L A B$ agrees with the report of Collins et al., (1983) who noted the inhibition of Psuedomonas fragi and $S$. aureus by hydrogen peroxide by some LAB strains which contribute to their inhibitory activity against other microorganisms.

The antibacterial compounds produced by $L A B$ obtained from femented food may be used to combat the growth of pathogenic microorganisms in the food industry. The use of bacteriocinogenic starter/protective cultures could improve the quality and increase safety by inhibiting the food-borne pathogens and spoilage microorganisms.

\section{REFERENCES}

Akobundu, E. N. T. and Hoskins, F. H. (1982). Protein losses in traditional agidi paste. Journal of Food Science 47, 1728-1729.

Association of official Analytical Chemists (A.O.A.C.) (1990). Methods of the Association of official Analytical Chemists, Benjamin Franklin Station, Washinton DC

Brinkten, B., Minekns, M., Vossen, M. V., Leer, R. J. and Huisin't Veld, J. H. J. (1994). Antimicrobial activity of lactobacilli. Journal of Applied Bacteriology 77, 140-148.

Brooks, G. F., Butel, J. S. and Morse, S. A. (1998). Medical Microbiology. $21^{\text {st }}$ edn. Norwalk. Conn. Appleton and Lange, USA. pp. 740.

Buckenhuskes, H. J. (1993). Selection criteria for lactic acid bacteria to be used as starter cultures for various food commodities. FEMS Microbiology Review 12, 253-272.

Calderon, M., Loiseau, G. and Guyot, J. P. (2001). Nutritional improvements and simplified cultivation medium to study growth and energetic of a sourdough lactic acid bacterium Lactobacillus 
fermentum Ogi E1 during heterolactic fermentation of starch. Journal of Applied Microbiology 90, 1-9.

Caplice, E. and Fitzgerald, G. F. (1999). Food fermentations: Role of microorganisms in food production and preservation. International Journal of Food Microbiology 50, 131-149.

Collins, M. D., Farrow, J. A., Phillips, B. A., and Kandler, O. (1983). Streptococcus garvieae sp. nov. and Streptococcus plantarum sp. nov. Journal of General Microbiology, 129(11), 3427-3431.

Daeschel, M. A. (1989). Antimicrobial substances from lactic acid bacteria for use as food preservatives. Food Technology, 43, 164-167.

Elaine, E., Vaughan, E. C., Looney, R., O'Rourke, N., Coveney, H., Daly, C. and Fitzgerald, G. F. (1994). Isolation from food sources of lactic acid bacteria that produced antimicrobials. Journal of Applied Bacteriology 76, 118-123.

Halm, M., Lillie, A., Srensen, A. K., and Jakobsen, M. (1993). Microbiological and aromatic characteristics of fermented maize dough for kenkey production in Ghana. International Journal of Food Microbiology 19, 135-143.

Holzapfel, W. H. Geisen, R. and Schillinger, U. (1995). Biological preservation of foods with reference to protective cultures, bacteriocins and food-grade enzymes International Journal of Food Microbiology 24 (3), 343-362.

Hounhouigan, D. J., Nout, M. J. R., Nago, C. M., Houben, J. H. and Rombouts, F. M. (1993). Characterization and frequency distribution of species of lactic acid bacteria involved in the processing of mawe, a fermented maize dough from Benin. International Journal of Food Microbiology 18, 115125.

Jay, J. M. (1982). Antimicrobial properties of diacetyl. Applied and Environmental Microbiology 44, 525-532.

Kingamkono, R., Sjogreen, E., Svanberg, U. and Kaijser, B. (1995). Inhibition of different strains of entero-pathogens in lactic fermenting cereal gruel. World Journal of Microbiology and Biotechnology 11, 299-303.

Klaenhammer, T. R. (1988). Bacteriocins of lactic acid bacteria. Biochimie 70(3), 337-349.

Kunene, N. F., Geornaras, I., von Holy, A., Hastings, J. W. (2000). Characterization and determination of origin of lactic acid bacteria from a sorghum-based fermented food by analysis of soluble proteins and amplified fragment length polymorphism fingerprinting. Applied Environmental Microbiology 66, 1084-1092.

Mead, P. S., Slutsker, L., Dietz, V., McCaige, L. F., Bresee, J. S., Shapiro, C., Griffin, P. M. and Tauxe, R. V. (1999). Food related illness and death in the United States. Emerging Infectious Diseases 5, 607625.

Mensah, P. (1997). Fermentation-the key to food safety assurance in Africa. Food Control 8, 271-278.

Obadina, A. O., Oyewole, O. B., Sanni, L. O. and Tomlins, K. I. (2006). Bio-preservative activities of
Lactobacillus plantarum strains in fermenting Casssava 'fufu' African Journal of Biotechnology 5 (8), 620-623.

Odunfa, S. A. (1985). African fermented foods. In: Microbiology of Fermented Foods. Vol. 2. Wood B. J. (ed.). Elsevier Applied Science Publishers, London and New York. pp. 35.

Ogunshe, A. A. O., Ayodele, A. E., and Okonko, O. (2005). Microbial studies on aisa - a potential indigenous laboratory fermented food condiment from Albiziz saman (Jacq.) F. Mull. Pakistan Journal of Nutrition 5(1), 51-58.

Olasupo, N. A., Olukoya, D. K., and Odunfa, S. A. (1995). Studies on bacteriocinogenic Lactobacillus isolates from selected Nigerian fermented foods. Journal of Bacteriology and Microbiology 39, 181186.

Olsen, A., Halm, M., and Jackobsen, M. (1995). The antimicrobial activity of lactic acid bacteria from fermented maize (kenkey) and their interactions during fermentation. Journal of Applied Bacteriology 79, 506-512.

Omemu, A. M., Oyewole, O. B. and Bankole, M. O. (2007). Significance of yeasts in the fermentation of maize for ogi production. Food Microbiology 24, 571 . 576.

Oranusi, S. U., Umoh, V. J., and Kwaga, J. K. P. (2003). Hazards and critical control points of Kunun-zaki, a non-alcoholic beverage in Northern Nigeria. Food Microbiology 20, 127-132.

Oyewole, O. B., 1997. Lactic fermented foods in Africa and their benefits. Food Control 8, 289-297.

Parente, E. and Ricciardi, A. (1999). Production, recovery and purification of bacteriocins from lactic acid bacteria. Applied Microbiology Biotechnology 52, 628-638.

Piard, J. C. and Desmazeaud, M. (1992). Inhibiting factors produced by lactic acid bacteria: 2 . Bacteriocins and other antibacterial substances. Lait 72, 113-142.

Teniola, O. D. and Odunfa, S. A. (1995). Indigenous microflora of ogi and their role as spoilage microorganisms. The third Biennial Seminar of African fermented foods, Ghana. pp.71-76.

Umoh, V. and Fields, M. J. (1981). Fermentation of corn for Nigerian Agidi. Journal of Food Science 46, 903905.

Wakil, S. M., Bamgbose, O. O., Ilo, E. C. (2004). Influence of fermentation time on the microbial profile, sensory attributes and shelf-life of "kunu-tsamia" Advances in Food Sciences 26 (2), 52-55. 